\title{
Alterations in T lymphocytes and T-lymphocyte subpopulations in patients with syphilis
}

\author{
J $\phi$ RGEN R JENSEN AND ELLIS FROM \\ From the Department of Dermatology and Venereology, University of Aarhus, Marselisborg Hospital, \\ Aarhus, Denmark
}

SUMMARY The distribution of T-lymphocyte subpopulations was studied in 34 patients with ${ }_{\mathscr{\sigma}}^{\omega}$ primary or secondary syphilis before and after treatment. An absolute and relative T lymphopenia $\stackrel{\text { ? }}{=}$. was found in all patients. In primary syphilis the concentration of helper cells $-\mathrm{T}$ cells with $\mathrm{Fc}_{\infty}^{\mathrm{c}}$ receptors for IgM $(\mathrm{T} \mu)$-was low whereas in secondary syphilis the suppressor cell concentra- $-\overrightarrow{.}$ tion-T cells with Fc receptors for IgG (Ty)-was reduced. Using lymphocytes from healthy $\vec{\infty}$ subjects this could be imitated in vitro by the addition of serum from patients with secondary 을 syphilis. In many autoimmune diseases a low concentration of $\mathrm{T} \gamma$ cells may be a primary factor in the production of autoantibodies. The occurrence of similar changes in patients with secondary $\mathbb{D}$ syphilis, however, indicates that such fluctuations in the T-cell subpopulations may take place during a strong immune response.

\section{Introduction}

In syphilis the appearance of heterologous antibodies is diagnostic of the disease and indicates polyclonal activation of B lymphocytes. At the same time various cell-mediated immune functions seem to be reduced. ${ }^{1-6}$ These findings indicate that patients with syphilis have an imbalance between B-cell activation and $T$ cells with immunoregulatory functions.

In the present investigation of patients with syphilis, characteristic changes were observed in the subpopulations of $T$ lymphocytes. These changes were related to the presence of antibodies and could be reproduced in vitro. The implication of these findings is discussed in relation to similar observations in patients with autoimmune diseases.

\section{Patients and methods}

STUDY POPULATION

Thirty-four patients with syphilis were studied. Their ages ranged from 16 to 44 years (mean $27 \cdot 2$ years). Seventeen had primary and 17 secondary syphilis. All had positive serological test results for syphilis. After syphilis had been diagnosed clinically, blood was collected for immunological investigations. The patients were then treated with procaine penicillin

Address for reprints: Dr J R Jensen, Department of Dermatology and Venereology, Marselisborg Hospital, 8000 Aarhus C, Denmark

Accepted for publication 14 July 1981 retard (PAM) 600000 IU daily for either 10 days (primary syphilis) or 14 days (secondary syphilis). The immunological investigations were repeated ones and two months after treatment.

Ninety-eight controls were studied, ranging in agen from 16 to 60 years (mean 29 years); these were staffo members and other individuals who had been screened for venereal disease and were without actualo disease at the time of the study.

ISOLATION OF MONONUCLEAR CELLS Lymphocytes from heparinised blood were isolated on Ficoll-Hypaque gradients and phagocytic cellsoremoved by the carbonyl iron incubation method $\underline{3}$. After separation, lymphocytes were washed three times in Hank's balanced salt solution (HBSS) with $2 \%$ fetal calf serum (FCS) and adjusted to $1 \times$ 을 $10^{6} / \mathrm{ml}$.

\section{ENUMERATION OF T LYMPHOCYTES}

One hundred microlitres of lymphocytes $(1 \times \mathrm{N}$ $10^{6} / \mathrm{ml}$ ) and $100 \mu \mathrm{l}$ of 2 -aminoethylisothiouronium $\sim$ bromide hydrobromide-treated sheep erythrocytes $(\mathrm{E}-\mathrm{AET})^{7}$ were incubated at $37^{\circ} \mathrm{C}$ for 15 minutes in ${ }^{\omega}$ RPMI-1640 with $20 \%$ FCS in a ratio of $1: 100$. The mixture was spun at $150 \times g$ for five minutes and incubated at $4^{\circ} \mathrm{C}$ for at least one hour. After $10 \mu \mathrm{l}$ of $0.1 \%$ acridine orange had been added the pellet was carefully resuspended, and 200 lymphocytes were counted with a fluorescence microscope. Lympho- $\overrightarrow{\mathbb{\Phi}}$ cytes with three or more erythrocytes bound to their surface were counted as rosette-forming cells. 
The subfraction of $T$ lymphocytes with high affinity to sheep erythrocytes form rosettes with untreated sheep erythrocytes (E-active or E-a rosettes). One hundred microlitres of lymphocytes suspended in RPMI-1640 without FCS were incubated with $100 \mu$ l untreated sheep erythrocytes in a ratio of $1: 10$ for five minutes at $37^{\circ} \mathrm{C}$. The mixture was spun for five minutes at $150 \times \mathrm{g}$, incubated at $4^{\circ} \mathrm{C}$ for five minutes, and resuspended for rosette enumeration.

\section{PURIFICATION OF T LYMPHOCYTES}

Five millilitres of E-AET and $5 \mathrm{ml}$ of lymphocytes were mixed and incubated as described above. After resuspension, Ficoll-Hypaque flotation was performed $(600 \times g$ for 15 minutes). The pellet of E-AET-rosetting $T$ lymphocytes was resuspended in $0.83 \%$ TRIS $\mathrm{NH}_{4} \mathrm{Cl}$ (10 minutes) to lyse the erythrocytes. After three washes with HBSS without serum the $\mathrm{T}$ lymphocytes were adjusted to a concentration of $1 \times 10^{6} / \mathrm{ml}$. Purity, as determined by E-AET rerosetting of the T-lymphocyte suspensions, was between $91 \%$ and $98 \%$. Lymphocytes with surface immunoglobulin (B lymphocytes) were not found in the purified T-lymphocyte suspensions.

PREPARATION OF ANTI-OX-RBC ANTIBODIES

Rabbits were immunised by weekly subcutaneous injections of $1 \mathrm{ml}$ of $10 \%$ ox red cells (ORBC) in Freund's incomplete adjuvant. Bleedings were performed weekly starting one week after the first immunisation. ${ }^{8}$ Serum was inactivated at $56^{\circ} \mathrm{C}$ for 30 minutes and IgG was purified by DEAE-cellulose ion-exchange chromatography. IgM was obtained by gel filtration (Ultrogel AcA 22, LKB). Both the IgG and IgM suspensions gave single peaks in a crossed immunoelectrophoresis against swine anti-rabbit immunoglobulins. Purity of the IgM suspension was further indicated by the lack of rosetting capacity of monocytes with ORBC coated with IgM antibodies; all monocytes with ORBC coated with IgG antibody, however, formed rosettes.

ERYTHROCYTE-ANTIBODY (EA) SUSPENSIONS ORBC-antibody complexes were prepared from ox erythrocytes in Alsevers solution, washed five times in HBSS, and resuspended to a concentration of $2 \%$. Subagglutinating concentrations of IgG or IgM antiORBC antibody were mixed with equal volumes of $2 \%$ ORBC and kept for 90 minutes at room temperature. Three washes of the ORBC-antibody complexes were done in HBSS with 2\% FCS. Finally, 10\% FCS was added. These erythrocyte-antibody (EA) suspensions were kept at $4^{\circ} \mathrm{C}$ and used during the next two days.
ENUMERATION OF T-LYMPHOCYTE SUBPOPULATIONS

Purified $\mathbf{T}$ lymphocytes were incubated in RPMI-1640 with $20 \%$ FCS at $37^{\circ} \mathrm{C}$ in a humidified $\mathrm{CO}_{2}$ atmosphere. After 24 hours' (day 1) and 48 hours' (day 2) incubation appropriate amounts of T lymphocytes were washed three times in HBSS with $2 \%$ FCS. The T lymphocytes $(0.01 \mathrm{ml})$ were mixed with ORBC coated with subagglutinating doses of either IgG $(0.01 \mathrm{ml})$ or $\operatorname{IgM}(0.01 \mathrm{ml})$, spun immediately at $150 \times g$ for five minutes, and incubated at $4^{\circ} \mathrm{C}$ for three hours. The percentage of cells forming rosettes was counted as described above.

\section{SERUM ASSAYS}

Immunoglobulins in serum from each of three patients with secondary syphilis were removed by ammonium sulphate precipitation. Sera from three controls were treated similarly. T lymphocytes from the three controls were cultured for 24 hours and incubated for 60 minutes at $37^{\circ} \mathrm{C}$ with autologous serum, autologous serum without immunoglobulins, syphilitic serum, and syphilitic serum without immunoglobulins. $T$ lymphocytes without addition of serum acted as controls. Serum was not inactivated by heat. Cell numbers and cell deaths were controlled before and after serum treatment. Three washes with HBSS with 2\% FCS were done before rosette enumeration.

STATISTICAL ANALYSIS

Student's $t$ test (two-tailed) was used.

\section{Results}

The total number of $\mathrm{T}$ lymphocytes (E-AET rosetteforming lymphocytes) was significantly reduced during both primary and secondary syphilis (table I). This was due to lymphopenia, since the percentage of $T$ lymphocytes was within the normal range although slightly reduced (table II).

The subfraction of $\mathrm{T}$ lymphocytes with high affinity for sheep erythrocytes (E-a rosette-forming lymphocytes) was also reduced (table I). In patients with primary syphilis both an absolute and relative reduction of E-a T lymphocytes was found, whereas in patients with secondary syphilis only the absolute number of E-a T cells was reduced (table II).

During primary syphilis the percentage of $T$ lymphocytes with Fc receptors for IgM $(T \mu)$ was significantly reduced. $T$ lymphocytes with $F c$ receptors for IgG $(\mathrm{T} \gamma)$ were slightly increased $\left(t_{98}=1 \cdot 50,0 \cdot 1<\mathrm{P}<0 \cdot 2\right.$; fig 1$)$. In patients with secondary syphilis this was almost reversed. The 
TABLE I Total number of T lymphocytes in peripheral blood from patients with syphilis and controls

\begin{tabular}{|c|c|c|c|c|}
\hline & \multicolumn{4}{|c|}{$T$ cells per $\mathrm{mm}^{3}$ (mean $\left.\pm S E M\right)(n):$} \\
\hline & Before treatment & $\begin{array}{l}\text { One month after } \\
\text { treatment }\end{array}$ & $\begin{array}{l}\text { Two months after } \\
\text { treatment }\end{array}$ & Controls \\
\hline \multicolumn{5}{|l|}{ E-AET } \\
\hline $\begin{array}{l}\text { Primary syphilis } \\
\text { Secondary syphilis }\end{array}$ & $\begin{array}{l}1479 \pm 213(9)^{*} \\
1579 \pm 183(13) \dagger\end{array}$ & $\begin{array}{l}2052 \pm 293(6) \\
2204 \pm 224(10)\end{array}$ & $\begin{array}{l}2045 \pm 228(7) \\
2651 \pm 352(9)\end{array}$ & $2089 \pm 73 \cdot 11(87)$ \\
\hline $\begin{array}{l}\text { Primary syphilis } \\
\text { Secondary syphilis }\end{array}$ & $\begin{array}{l}829 \pm 63(9) \ddagger \\
882 \pm 83(12) \S\end{array}$ & $\begin{array}{l}1175 \pm 157(7) \\
1302 \pm 130(12)\end{array}$ & $\begin{array}{l}1061 \pm 229(6) \\
1477 \pm 245(8)\end{array}$ & $1179 \pm 47 \cdot 24(84)$ \\
\hline
\end{tabular}

SEM = standard error of mean; $\mathbf{n}=$ No of patients or controls; $\mathrm{E}$-AET $=2$-aminoethylisothiouronium bromide hydrobromide-treated sheep $\rightarrow$ erythrocytes; $\mathrm{E}-\mathrm{a}=$ untreated sheep erythrocytes

*Significantly reduced $\left(t_{94}=2 \cdot 71, \mathrm{P}<0 \cdot 01\right)$

†Significantly reduced $(t 98=2 \cdot 58, \mathrm{P}<0 \cdot 02)$

$¥$ Significantly reduced $\left(t_{91}=4 \cdot 45, \mathrm{P}<0 \cdot 005\right)$

$\S$ Significantly reduced $\left(t_{94}=3 \cdot 12 ; \mathrm{P}<0 \cdot 005\right)$

TABLE II Percentage of T lymphocytes in peripheral blood from patients with syphilis and controls

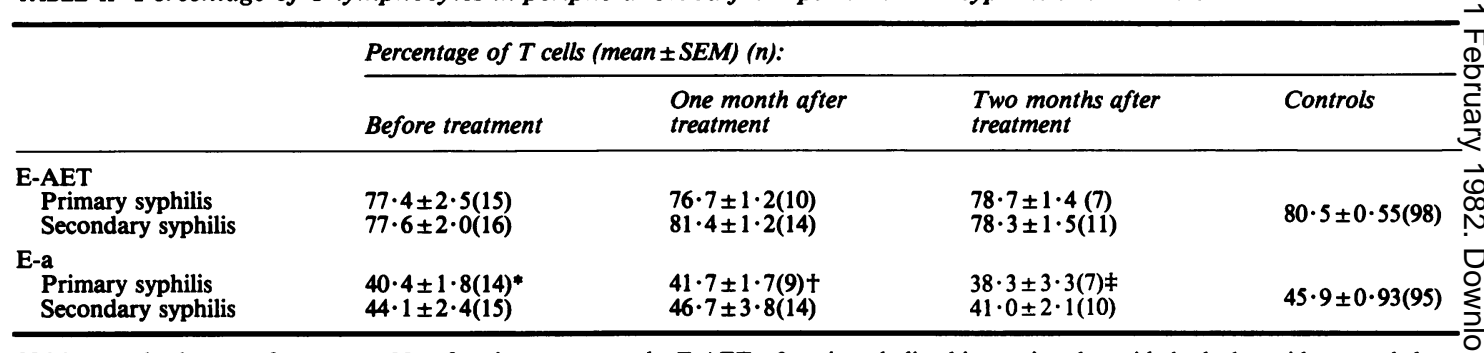

SEM = standard error of mean; $n=$ No of patients or controls; E-AET = 2-aminoethylisothiouronium bromide hydrobromide-treated sheep erythrocytes; $\mathrm{E}-\mathrm{a}=$ untreated sheep erythrocytes

*Significantly reduced $\left(t_{107}=2 \cdot 7, \mathrm{P}<0 \cdot 01\right)$

tSignificantly reduced $\left(t_{102}=2 \cdot 15, \mathrm{P}<0 \cdot 05\right)$

$\neq$ Significantly reduced $\left(t_{100}=2 \cdot 23, P<0.05\right)$

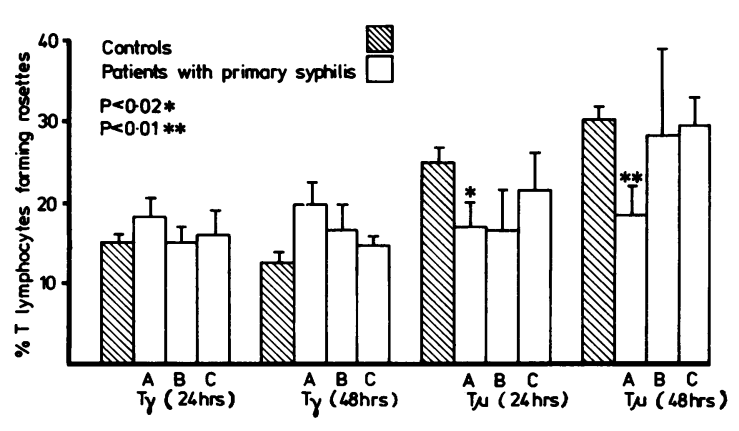

FIG 1 The percentage of $T \gamma$ and $T \mu$ rosettes in patients with primary syphilis before treatment $(A, n=14)$, one month after $(B, n=7)$, and two months after treatment $(C, n=7)$ in $T$ cells cultured for 24 hours and 48 hours compared with controls $(n=84)$. Results represent mean \pm SEM (Student's $t$ test).

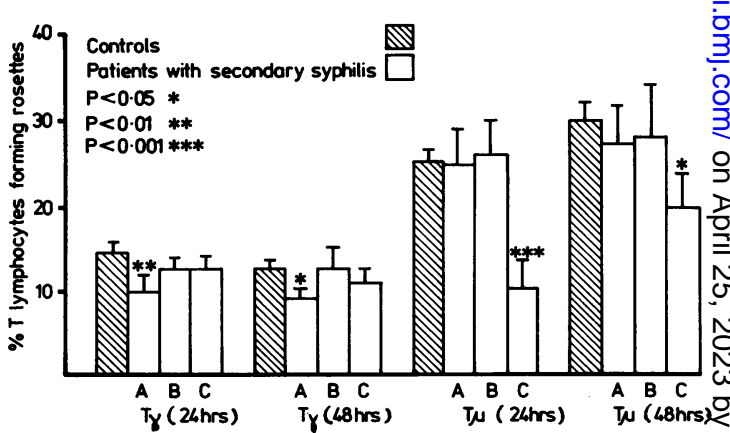

FIG 2 The percentage of $T \gamma$ and $T \mu$ rosettes in patients with secondary syphilis before treatment $(A, n=9)$, one month after $(B, n=11)$, and two months after treatment (C, $n=12$ ) in T cells cultured for 24 hours and 48 hours compared with controls $(n=84)$. Results represent mean $\pm S E M$ (Student's $t$ test). 
percentage of $\mathrm{T} \mu$ lymphocytes was normal whereas that of $\mathrm{T} \gamma$ cells was significantly reduced (fig 2 ).

The reduced percentage of $\mathrm{T} \gamma$ cells during the secondary stage was investigated in vitro by adding serum from each of three patients with secondary syphilis to $\mathrm{T}$ lymphocytes from three healthy donors. Complement was not inactivated by heat. The expression of the Fc-IgG receptor on the T lymphocytes was significantly reduced without selective killing of $\mathrm{T}_{\gamma}$ cells $\left(t_{2}=6 \cdot 48, \mathrm{P}<0.025\right)$. When the immunoglobulin in serum was removed through ammonium sulphate precipitation this effect disappeared (table III). No reduction of the expression of the Fc-IgM receptor was observed in similar experiments using serum from a patient with primary syphilis (results are not shown).

\section{Discussion}

The importance of cell-mediated immunity (CMI) in syphilis is suggested by T-lymphocyte depletion in the paracortical areas of lymph nodes and the periarteriolar area of the spleen in children with fatal congenital syphilis. ${ }^{910}$ In rabbits, the infection takes a severe course if $\mathrm{T}$ lymphocytes are destroyed by cyclophosphamide treatment. ${ }^{11}$ In patients with syphilis evidence has been found for a depression in CMI, which involves cutaneous reactivity, ${ }^{1}$ low T-cell numbers, ${ }^{6}$ low in-vitro reactivity to Treponema pallidum, ${ }^{13-5}$ and immunosuppressive factors in serum. ${ }^{12}$

This study demonstrates that the total number of $T$ lymphocytes are reduced in patients with early syphilis. The $\mathrm{T}$ lymphopenia may be due to an unequal distribution of lymphocytes in the lymphoid system, although a depletion of lymphocytes is also seen in histological examinations of enlarged lymph nodes during early syphilis. ${ }^{12}$ Another possibility is that cytotoxic antibodies to $\mathrm{T}$ lymphocytes may occur, although lymphocytotoxic antibodies were shown to be active only at $15^{\circ} \mathrm{C}$. $^{13}$ Also, the $\mathrm{T}$ lymphopenia disappears rapidly after treatment and the serum assays do not show any enhanced cell death. A third possibility is that $T$ pallidum itself is directly toxic to $\mathrm{T}$ lymphocytes.

It has been proposed that $\mathrm{T}$ lymphocytes with $\mathrm{Fc}$ receptors may function as helper $(\mathrm{T} \mu)$ or suppressor (Ty) cells. ${ }^{14}$ In primary syphilis the $T \mu$-cell concentration was low, consistent with compartmentalisation of helper cells-that is, an unequal distribution of lymphocytes in the body during an immune response. ${ }^{15}$ Compartmentalisation of helper cells occurs during early antibody production. ${ }^{16}{ }^{17} \mathrm{The} \mathrm{T} \gamma$ cell concentration was increased, perhaps as a result of suppressor-cell activation. ${ }^{18}$

In patients with secondary syphilis the $\mathrm{T} \mu$-cell concentration was normal until two months after treatment when a fall occurred. The reason for this fall is obscure. During active secondary syphilis the $\mathrm{T} \gamma$-cell concentration was significantly reduced. Explanations for this may be similar to those for the T lymphopenia. Furthermore, during secondary syphilis immune complex formation takes place, ${ }^{19}$ and it is well known that immune complexes interact in vitro with $\mathrm{T} \gamma$ cells leading to an irreversible loss of the Fc receptor for $\mathrm{IgG}^{20}$ This mechanism may explain the reduction of the $T \gamma$ cells in peripheral blood as indicated by the results from the serum assays (table III). No similar mechanism seemed to operate in primary syphilis.

It has been found that $\mathrm{Tr}$ cells activated by pokeweed mitogen and immune complexes release immunosuppressive factors. ${ }^{21} T$ pallidum may give an in-vivo stimulation, which in conjunction with immune complexes stimulates $\mathrm{T} \gamma$ cells to release immunosuppressive factors. This may explain the

TABLE III Effect of secondary syphilitic serum on homologous T lymphocyte subpopulations in three controls

\begin{tabular}{|c|c|c|c|c|}
\hline \multirow[b]{2}{*}{ Donor serum (40\%) } & \multirow[b]{2}{*}{ Subpopulations } & \multicolumn{3}{|c|}{ Percentage of $T$ lymphocyte subpopulations in controls: } \\
\hline & & Control 1 & Control 2 & Control 3 \\
\hline Autologous serum & $\begin{array}{l}\mathrm{T} \gamma \\
\mathrm{T} \mu\end{array}$ & $\begin{array}{r}9 \cdot 0 \\
31 \cdot 5\end{array}$ & $\begin{array}{l}15 \cdot 0 \\
53 \cdot 0\end{array}$ & $\begin{array}{l}13 \cdot 0 \\
40 \cdot 5\end{array}$ \\
\hline $\begin{array}{l}\text { Autologous serum } \\
\text { without Ig }\end{array}$ & $\begin{array}{l}\mathrm{T} \gamma \\
\mathrm{T} \mu\end{array}$ & $\begin{array}{r}9 \cdot 5 \\
29 \cdot 5\end{array}$ & $\begin{array}{l}18 \cdot 0 \\
36 \cdot 5\end{array}$ & $\begin{array}{l}16 \cdot 0 \\
39 \cdot 0\end{array}$ \\
\hline $\begin{array}{l}\text { Secondary syphilitic } \\
\text { serum }\end{array}$ & $\begin{array}{l}\mathrm{T} \gamma^{*} \\
\mathrm{~T} \mu\end{array}$ & $\begin{array}{r}3 \cdot 0 \\
33 \cdot 0\end{array}$ & $\begin{array}{r}4 \cdot 0 \\
50 \cdot 5\end{array}$ & $\begin{array}{r}4 \cdot 0 \\
43 \cdot 5\end{array}$ \\
\hline $\begin{array}{l}\text { Secondary syphilitic } \\
\text { serum without Ig }\end{array}$ & $\begin{array}{l}\mathrm{T} \gamma \\
\mathrm{T} \mu\end{array}$ & $\begin{array}{r}8 \cdot 5 \\
33 \cdot 0\end{array}$ & $\begin{array}{l}17 \cdot 0 \\
37 \cdot 0\end{array}$ & $\begin{array}{l}14 \cdot 0 \\
43 \cdot 0\end{array}$ \\
\hline Controls without serum & $\begin{array}{l}\mathrm{T}_{\gamma} \\
\mathrm{T} \mu\end{array}$ & $\begin{array}{l}11 \cdot 0 \\
33 \cdot 0\end{array}$ & $\begin{array}{l}20 \cdot 0 \\
36 \cdot 0\end{array}$ & $\begin{array}{l}17 \cdot 5 \\
40 \cdot 5\end{array}$ \\
\hline
\end{tabular}

*Significant reduction $\left(78 \% ; t_{2}=6 \cdot 48, \mathrm{P}<0 \cdot 025\right)$ 
reduced cutaneous reactivity in syphilitic patients ${ }^{1}$ and the depressed in-vitro functions of lymphocytes from peripheral blood. ${ }^{13-5}$

Reduction of the $\mathrm{T} \gamma$-cell concentration has been observed in various autoimmune diseases and in other diseases with increased antibody production. ${ }^{22-28}$ The increased antibody production may be caused by direct polyclonal B-cell activation or indirectly by a defective suppressor-cell mechanism, which may be a primary disorder or secondary to the occurrence of lymphocytotoxic antibodies or immune complexes. In systemic lupus erythematosus (SLE) the suppressor-cell defect is mainly a quantitative rather than a qualitative disorder. ${ }^{29}$ Immunosuppressive factors, which depress nonspecific suppressor-cell activity, have also been found in SLE. ${ }^{30} 31$

The changes observed in the subpopulations of $T$ lymphocytes occurred during an infectious disease in young subjects who were not suspected of having any immune deficiencies. These changes are similar to those found in various diseases with an imbalance between an increased B-cell activity and signs of reduced immunoregulatory $\mathrm{T}$ cells. ${ }^{22-28}$ Our findings seem to show that the changes in immunoregulatory $T$ cells may be secondary to a strong immune reaction -that is, treponemal infection.

This work was supported by the Danish Medical Research Council, grants Nos 512-15133, 512-20160, and 512-20207. We wish to thank Mrs A Jespersen and $J$ Schj申th for technical assistance and Dr $K$ Thestrup-Pedersen for his constant encouragement and for reviewing the manuscript.

\section{References}

1. From E, Thestrup-Pedersen $K$, Thulin H. Reactivity of lymphocytes from patients with syphilis towards $T$ pallidum antigen in the leucocyte migration and lymphocyte transformation tests. Br J Vener Dis 1976; 52:224-9.

2. Levene GM, Turk JI, Wright DJM, Grimble AGS. Reduced lymphocyte transformation due to a plasma factor in patients with active syphilis. Lancet 1969; ii:246-7.

3. Fulford KWM, Brostroff J. Leucocyte migration and cellmediated immunity in syphilis. Br J Vener Dis 1972;48:483-8.

4. Pavia CS, Baseman JB, Folds JD. Selective response of lymphocytes from Treponema pallidum-infected rabbits to mitogens and Treponema reiteri. Infect Immun 1977; 15: 417-22.

5. Pavia CS, Folds JD, Baseman JB. Selective in-vitro response of thymus-derived lymphocytes from Treponema palliduminfected rabbits. Infect Immun 1977; 18:603-11.

6. Bos JD, Hamerlinck F, Cormane RH. T lymphoid cells in primary syphilis. Quantitative studies. Br J Vener Dis 1980; 56:74-6.

7. Kaplan ME, Clark C. An improved rosetting assay for the detection of human T lymphocytes. J Immunol Methods 1974; 5:131-5.

8. Gupta S, Good RA. Subpopulations of human T lymphocytes I. Studies in immunodeficient patients. Clin Exp Immunol 1977; 30:222-8.

9. Levene GM, Wright DJM, Turk JL. Cell-mediated immunity and lymphocyte transformation in syphilis. Proc $R$ Soc Med $1971 ; 64: 426-8$.
10. Wright DJM, Grimble AS. Why is the infectious stage of syphilis prolonged? Br J Vener Dis 1974; 50:45-9.

11. Pacha J, Metzger M, Smogór W, Michalska E, Podwinska J, Ruczkowska J. Effect of immunosuppressive agents on the course of experimental syphilis in rabbits. Arch Immunol Ther Ex (Warsz) 1979; 27:45-51.

12. Turner DR, Wright DJM. Lymphadenopathy in early syphilis. $J$ Pathol 1973; 110:305-8.

13. de Jong NHL, Koehorst JAM, van der Sluis JJ, Boer AM. Autolymphocytotoxins in syphilis. Br J Vener Dis 1980;56: 297-301.

14. Moretta L, Webb SR, Grossi CE, Lydyard PM, Cooper MD. Functional analysis of two human T-cell subpopulations, help and suppression of B-cell responses by $\mathrm{T}$ cells bearing receptors for IgM and IgG. J Exp Med 1977; 146: 184-200.

15. Schlossman SF, Levin HA, Rocklin RE, David JR. The com-: partmentalization of antigen-reactive lymphocytes in desen- $\overrightarrow{-}$ sitized guinea pigs. J Exp Med 1971, 134:741-50.

16. Lagrange $\mathbf{P H}$, Mackaness $\mathrm{GB}$, Miller TE. Influence of dose and route of antigen injection on the immunological induction? of T cells. $J$ Exp Med 1974; 139: 528-42.

17. Hahn H, Kaufmann SHE, Falkenberg F, Chahinin M, Horno W. Peritoneal exudate T lymphocytes with specificity to sheepred blood cells. II Inflammatory helper $\mathrm{T}$ cells and effector $\mathrm{T} \rightarrow \overrightarrow{ }$ cells in mice with delayed-type hypersensivity and in suppressed $\infty$ mice. Immunology 1979; 38:51-5.

18. Ramshaw IA, Bretscher PA, Parish CR. Regulation of the immune response. I Suppression of delayed type hypersensivity by $\mathrm{T}$ cells from mice expressing humoral immunity. Europ $J$ T Immunol 1979; 6:674-9.

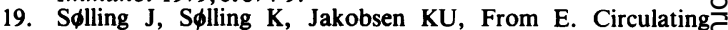
immune complexes in syphilis. Acta Derm Venereol (Stockh) D 1978;58:263-7.

20. Pichler WJ Lum L, Border S. Fc receptors on human T lymphocytes. I Transition of $\mathrm{T} \gamma$ to $\mathrm{T} \mu$ cells. J Immunolco 1978;121: 1540-8.

21. Moretta L, Mingari MC, Moretta A, Cooper MD. Human T-lymphocyte subpopulations: studies of the mechanism by which $T$ cells bearing $F c$ receptors for IgG suppress T-dependent B cell differentiation induced by PWM. $J$ Immunol 1979; 122:984-90.

22. Fauci AS, Steinberg AD, Haynes BF, Whalen G. Immunoregulatory abberrations in systemic lupus erythematosus. $J$ 응 Immunol 1978; 121: 1473-9.

23. Alarcón-Segovia D, Ruiz-Argüelles A. Decreased circulationthymus-derived cells with receptors for the Fc portion of immunoglobulin $\mathrm{G}$ in systemic lupus erythematosus. J Clin Invest 1978; 62: 1390-4.

24. Reinherz EL, Rubinstein A, Geha RS, Strelkauskas AJ, Rosen FS, Schlossman SF. Abnormalities of immunoregulatory TO cells in disorders of immune function. $N$ Engl $J$ Med 1979; 301: 1018-22.

25. Sandilans GP, Galbraith I, Reid FM, Mills PR, MacSween RMN. Immune-complex inhibition of lymphocyte Fc receptors in primary biliary cirrhosis. A possible immunomodulatory. mechanism. Lancet 1980; ii:9-13.

26. Reinherz EL, Weiner HL, Hauser SL, Cohen JA, Distaso JA, Schlossman SF. Loss of suppressor $T$ cells in active multiple sclerosis. Analysis with monoclonal antibodies. $N$ Engl J Med음 1980; 303: 125-9.

27. Bach M-A, Phan-Dinh-Tuy F, Tournier E, Chatenoud L, Bach $\mathrm{J}-\mathrm{F}$. Deficit of suppressor $\mathrm{T}$ cells in active multiple sclerosis. Lancet 1980; ii: $1221-3$.

28. Jensen JR, Cramers M, Thestrup-Pedersen K. Subpopulations $N$ of $T$ lymphocytes and non-specific suppressor-cell activity inpatients with atopic dermatitis. Clin Exp Immunol 1981; N 45: 118-23.

29. Moretta M, Mingari MC, Santoli, D, Perlman P, Moretta L.W Human T-lymphocyte subpopulations: alterations in systemico lupus erythematosus. Scand J Immunol 1979; 10:223-8.

30. Sagawa A, Abdou NI. Suppressor-cell antibody in systemi£ lupus erythematosus. Possible mechanism for suppressor-cell dysfunction. J Clin Invest 1979;63:536-9.

31. Sakane T, Steinberg AD, Reeves JP, Green I. Studies of immune functions of patients with systemic lupus erythe-T matosus. Complement-dependent immunoglobulin $\mathbf{M}$ anti-O thymus-derived cell antibodies preferentially inactivated suppressor cells. J Clin Invest 1979; 63:954-65. 